\title{
Apparent Digestibility Coefficients of Nutrients in Diets Containing Jatropha curcas seedmeal by Oreochromis niloticus
}

\author{
W.A. Jimoh ${ }^{1 *}$, M.O. Shittu ${ }^{2}$, A.A. Ayeloja ${ }^{1}$, S.A. Abdulsalami ${ }^{3}$ and F.Y. Okemakin ${ }^{4}$ \\ Date Received: $18^{\text {th }}$ November 2019 / Date Accepted: $1^{\text {st }}$ July 2020
}

\begin{abstract}
Purpose: Apparent digestibility coefficients of nutrients in Jatropha curcas based diets were evaluated for Nile tilapia (Oreochromis niloticus) using AIA as marker or indicator.

Research Method: A total of 225tilapia were acclimatized for a week, weighed and allotted into five dietary treatments; containing 20 and 40\% of 5- and 10-minute toasted Jatropha curcas replacing soybean meal in control diets. The diets were isonitrogenous and isolipidic. Each treatment was replicated three times with fifteen fish per replicate. Fish were fed 5\% body weight on two equal proportions per day. Acid insoluble ash and digestibility coefficient determinations followed standard established procedures.

Findings : The results from the study indicated that the apparent digestibility coefficients of nutrients in control diets were significantly $(p<0.05)$ higher than that test diets containing Jatropha curcas seedmeal. There was a reduction in the apparent digestibility coefficients of nutrients in the diet with increase replacement levels which were significant $(p<0.05)$ at a 10-minute processing time. However, no significant difference ( $p>0.05)$ was observed in the apparent digestibility coefficient of nutrients in 5-minute toasted Jatropha up to $40 \%$ soybean replacement among the fish fed the diet. So also, the apparent carbohydrate digestibility coefficient of the different test dietary treatments was not statistically different $(p>0.05)$.
\end{abstract}

Originality / Value : It is evident from this study that diets containing Jatropha curcas seedmeal were relatively well digested by Oreochromis niloticus compared with soybean-based diets.

Keywords: Jatropha, apparent protein digestibility, tilapia, acid insoluble ash, apparent lipid digestibility

\section{INTRODUCTION}

The recent increase in aquaculture development in Nigeria and world at large is accompanied by the need to incorporate plant materials in fish feed (Hardy, 2010) so as to dispense total reliance on conventional legumes that have successfully replaced fishmeal. Soybean that could replace not less than $50 \%$ of the fishmeal in the diet of fish species is not so much available in the market and commands a high price because of its competitive use as food by man and feed ingredients by other livestock feed producers (Siddhuraju and Becker, 2001). There is therefore, a need to shift priority to searching for alternative plant protein feed ingredient of little or no use and cheaper in terms of cost to replace these conventional legumes. The search for alternative feedstuff to the current conventional feed ingredients requires that the digestibility of the alternative feed ingredients be favourably comparable to the conventional feed ingredients (Sarker et al., 2006). The nutrient digestibility coefficients of various feed ingredients would show how possible feed ingredients can be interchanged without reducing performance of the animal in terms

\footnotetext{
Department of Aquaculture and Fisheries, University of Ilorin, PMB 1515, Ilorin, Nigeria.

jimoh.wa@unilorin.edu.ng

2 Department of Fisheries Technology, Federal College of Animal Health and Production Technology, PMB 5029, Ibadan, Nigeria.

3 Fisheries and Aquaculture Unit, Department of Biological Sciences, Crescent University, Abeokuta, Ogun State, Nigeria.

4 Department of Biology, The Polytechnic, Ibadan, Nigeria.

(1) ORCID http://orcid.org/0000-0003-0174-301X
} 
protein accretion and reproductive performance (Borghesi et al., 2008). Koprucu and Ozdemer (2005) reported apparent digestibility coefficient (ADC) results afford one to precisely estimate the contribution of a particular protein source to a complete fish feed. Recent studies that focused on the use of digestibility coefficients to evaluate the potential of alternative protein source feed ingredients in fish diets are lima beans in Oreochromis niloticus diet (Adeparusi and Jimoh 2002); jackmeal in Oreochromis niloticus diet (Jimoh et al., 2010); sesame and sunflower seedmeal in Clarias garipinus diet (Fagbenro et al., 2013); watermelon seedmeal in tilapia diets (Jimoh et al., 2015).

Direct and indirect methods have been used to study digestibility. Most of the digestibility studies in aquaculture nutrition have identified indirect methods as being reliable in carrying out digestibility study for fish (Takeuchi et al., 1979; Wilson and Poe, 1985; Satoh et al., 1992) Based on the concentration of an indigestible marker (exogenous and endogenous markers) in the feed and in the fecal samples, the digestibility coefficients of the feed or feed ingredients are determined. The efficacy of the external and internal markers was tested by Halver et al., (1993) who reported that endogenous marker especially Acid Insoluble Ash (AIA) was a more reliable indicator of digestibility coefficient as the dietary ingredient (ash) is used and analysis of this component in feed and faeces uses simple gravimetry method. Goddard and McLean (2001) reported that there was no significant difference in apparent digestibility coefficients for nitrogen, dry matter or gross energy determined in a practical diet using naturally occurring AIA. Smith, (1989) reported the various methods of sampling faeces to be used in digestibility analysis; may be obtained from the lower large intestine by suction method or obtained by gentle pressure in the abdomen of the fish or periodically removed from the tank by siphoning or the use of settling column. This work therefore, seeks to evaluate the apparent digestibility coefficients of nutrients in the diets containing Jatropha seedmeal fed to Oreochromis niloticus using AIA as an indicator.

\section{MATERIALS AND METHODS}

\section{Collection and processing of Jatropha curcas seed}

Mature seed Jatropha curcas were obtained from Ilora, Oyo town, Nigeria. The seeds were stored at room temperature in polyethene bags. The seeds of Jatropha curcas were obtained and divided into two parts, the first part was roasted for 5 minutes and the second part was roasted for 10 minutes. The 5- and 10-minute toasted Jatropha seed meal, soybean meal, fishmeal and corn were then taken to the laboratory for proximate composition analyses following the procedure of AOAC (1990).

\section{Diet formulation and preparation}

Five experimental diets were made based on proximate composition of the basic feed ingredients in Table 01; the control diet consisted of fishmeal and soybean meal as the major protein-source feed ingredients. The soybean meal portion of the control diets were replaced at a rate of $20 \%$ and $40 \%$ by 5 - and 10 -minute toasted Jatropha curcas seed meal to make the rest four test diets. The ingredients were manually mixed together in the laboratory before the addition of vitamin premix. Fish oil was later added to the dry ingredients and mixed thoroughly. Warm water was added to the pre-mixed ingredients and homogenized until a dough-like paste was formed. The dough was passed through an improvised manual pelleting machine to produce $2 \mathrm{~mm}$ pellet size. The moist pellets were sun-dried to a constant weight which were thereafter, kept in air tight containers. The gross composition of the experimental diets is given in Table 02.

\section{Experimental Design}

Juveniles of Oreochromis niloticus were obtained from a reputable source in Ibadan Oyo state, Nigeria. The experimental design was a completely randomized design with three 
replicates per treatment and each replicate had 15 juvenile tilapia. The fish were acclimatized for 15 days wherein they were group fed on commercial diet. All the fish were starved for 24 hours prior to the commencement of the feeding trial to prepare their gastrointestinal tract for the experimental diet while at the same time to increase the appetite of the fish.

\section{Feeding Trial}

Each of the experimental diets was allotted to three experimental tanks and all the fish were fed twice daily at a fixed feeding rate of 5\% of their body weight per day with each of the experimental diets. Feeding was generally done in the morning at 09:00 am and 05:00 pm in the evening.

\section{Proximate Analyses}

The proximate analyses of feed ingredients, diets and faeces for crude protein, crude fibre, crude lipid, fat and ash were carried out in triplicate using the methods described by the AOAC, (1990). A factor of 6.25 was used to convert nitrogen to protein. The nitrogen free extract was estimated by difference. Energy content of faeces and diets were determined using the physiological value of $5.61 \mathrm{kcal} / \mathrm{g}$ protein $4.11 \mathrm{kcal} / \mathrm{g}$ carbohydrate and $9.50 \mathrm{kcal} / \mathrm{g}$ lipid.

\section{Digestibility Studies}

Digestibility procedures followed the method described by Fagbenro et al., (2013). Determination of AIA and digestibility coefficient followed the method explained in Jimoh et al., (2010).

Table 01: Proximate composition of the some feed ingredients

\begin{tabular}{lccccc}
\hline \multicolumn{1}{c}{ Parameter } & Fish meal & Soybean Meal & 5-Min TJCM & 10-min TJCM & Maize \\
\hline Moisture & 9.75 & 10.70 & 3.80 & 3.80 & 10.48 \\
Crude Protein & 72.4 & 38.74 & 33.96 & 34.72 & 9.87 \\
Crude Lipid & 10.45 & 17.68 & 19.03 & 19.43 & 4.28 \\
Crude Fibre & - & 5.10 & 13.11 & 10.16 & 5.78 \\
Ash & 8.32 & 4.48 & 6.09 & 4.25 & 6.73 \\
$*$ NFE & - & 23.30 & 24.01 & 27.64 & 62.35 \\
\hline
\end{tabular}

*Nitrogen Free Extract ; TJCM Toasted Jatropha curcas meal

Table 02: $\quad$ Gross composition $(\mathrm{g} / \mathbf{1 0 0 g})$ of experimental diets containing diffrently timed dry heat treated Jatropha curcass seedmeal fed to Oreochromis niloticus

\begin{tabular}{lccccc}
\hline \multicolumn{1}{c}{ Ingredients } & CTR & D520T & D540T & D1020T & D1040T \\
\hline Fishmeal & 20.83 & 20.83 & 20.83 & 20.83 & 20.83 \\
Soybean Meal & 42.10 & 33.68 & 25.62 & 33.68 & 25.62 \\
5-Min Toasted & - & 9.42 & 18.85 & - & - \\
10-Min Toasted & - & - & - & 9.21 & 18.43 \\
Corn & 10.00 & 10.00 & 10.00 & 10.00 & 10.00 \\
Fish Premix & 5.00 & 5.00 & 5.00 & 5.00 & 5.00 \\
Fish Oil & 2.50 & 2.50 & 2.50 & 2.50 & 2.50 \\
Starch & 19.57 & 18.59 & 17.20 & 18.78 & 17.62 \\
Total & 100.00 & 100.00 & 100.00 & 100.00 & 100.00 \\
\hline
\end{tabular}

Specification: each $\mathrm{kg}$ fish premix contains: Vitamin A, 4,000,000IU; Vitamin B, 800,000IU; Vitamin E, 40,000IU, Vitamin $K_{3}, 1,600 \mathrm{mg}$; Vitamin $B_{1}$, 4,000mg; Vitamin $B_{2}$, 3,000mg; Vitamin $B_{6}, 3,800 \mathrm{mg}$, Vitamin $B_{12} 3 \mathrm{mcg}$; Nicotinic Acid 18000mg. Pantothenic Acid 8,000mg; Folic Acid 800mg Biotin, 100 mcg Choline Chloride 120,000mg; Iron 8,000mg; Copper 800mg; Manganese, 6,000mg; Zinc 8,000mg; Iodine 400mg;; Selenium, 40 mcg,vit C Coated 60,000mg,Inositol 10,000mg; Cobalt,150m, Lysine 10,000mg; Methionine 10,000 mg, Antioxidant 25,000mg manufactured by Bi-mix Brrand, Corporate head office/factory: 1, Odo-Olowu Street, Ijesatedo, Lagos, Nigeria. 


\section{RESULTS AND DISCUSSION}

Table 03 reveals the proximate composition of the experimental diets. The diets were isonitrogenous and isolipidic as there existed no significant variations $(\mathrm{p}>0.05)$ in the crude protein and crude lipid of the different dietary treatments. The protein and lipid requirement of the fish were met by the amount provided for in the diet (Luquet, 1991).

The proximate composition of the faecal samples of fish fed diets containing Jatropha curcas is shown in in Table 04. There was a reduction in the proximate composition of the faecal samples when compared to that of the diets. The components of the proximate composition were significantly $(p<0.05)$ higher in the faeces of fish fed D1020T and D1040T. Marked reduction was observed in the proximate composition of the faecal samples of fish fed control and test diets when compared with proximate composition of the experiment diet. This was also observed by Adeparusi and Jimoh (2002); Jimoh et al., (2010); Fagbenro et al., (2013) and Jimoh et al., (2014).

The acid insoluble ash (AIA) contents in the faeces and diets are presented in Table 05 . Faecal AIA were higher in value than that of the diets. Fish fed D1040T had significantly $(p<0.05)$ higher AIA in their diets and faeces. The faecal AIA that was higher in value than the experimental diets fed to Nile tilapia in this study was also reported by Gul et al., (2007) that the quantity of the indicator (Chromic oxide) was more in the faeces than in the feed; Fagbenro et al., (2013) also reported higher faecal AIA in the faeces of Clarias gariepinus fed sunflower and sesame seedmeal when compared with the diet fed.

Table 03: $\quad$ Proximate composition (g/100g Dry Matter) of experimental diets

\begin{tabular}{lccccc}
\hline \multicolumn{1}{c}{ Parameters } & CTR & D520T & D540T & D1020T & D1040T \\
\hline Moisture & $9.95 \pm 0.17^{\mathrm{a}}$ & $10.06 \pm 0.12^{\mathrm{a}}$ & $9.70 \pm 0.17^{\mathrm{a}}$ & $10.16 \pm 0.16^{\mathrm{a}}$ & $9.94 \pm 0.25^{\mathrm{a}}$ \\
Crude Protein & $35.17 \pm 0.05^{\mathrm{a}}$ & $35.18 \pm 0.08^{\mathrm{a}}$ & $35.18 \pm 0.01^{\mathrm{a}}$ & $35.17 \pm 0.01^{\mathrm{a}}$ & $35.16 \pm 0.01^{\mathrm{a}}$ \\
Crude Lipid & $10.49 \pm 0.24^{\mathrm{a}}$ & $10.66 \pm 0.31^{\mathrm{a}}$ & $10.38 \pm 0.06^{\mathrm{a}}$ & $10.38 \pm 0.01^{\mathrm{a}}$ & $10.38 \pm 0.01^{\mathrm{a}}$ \\
Crude Fibre & $11.92 \pm 0.14^{\mathrm{c}}$ & $12.40 \pm 0.49^{\mathrm{bc}}$ & $12.60 \pm 0.11^{\mathrm{b}}$ & $13.16 \pm 0.16^{\mathrm{a}}$ & $13.27 \pm 0.40^{\mathrm{a}}$ \\
Ash & $6.44 \pm 0.01^{\mathrm{b}}$ & $6.50 \pm 0.03^{\mathrm{ab}}$ & $6.52 \pm 0.03^{\mathrm{a}}$ & $6.37 \pm 0.06^{\mathrm{c}}$ & $6.19 \pm 0.02^{\mathrm{d}}$ \\
NFE & $26.04 \pm 0.1^{\mathrm{a}}$ & $25.20 \pm 0.39^{\mathrm{bc}}$ & $25.62 \pm 0.25^{\mathrm{ab}}$ & $24.75 \pm 0.35^{\mathrm{c}}$ & $25.06 \pm 0.33^{\mathrm{bc}}$ \\
Energy $(\mathrm{kcal} / \mathrm{g})$ & $4.00 \pm 0.03^{\mathrm{a}}$ & $4.02 \pm 0.03^{\mathrm{ab}}$ & $4.01 \pm 0.01^{\mathrm{ab}}$ & $3.97 \pm 0.02^{\mathrm{b}}$ & $3.99 \pm 0.01^{\mathrm{bc}}$ \\
\hline
\end{tabular}

Row means with different superscripts are significantly different $(p<0.05)$ from each other

Table 04: $\quad$ Proximate composition of the faecal samples of Oreochromis niloticus

\begin{tabular}{lccccc}
\hline & CTR & D5020T & D5040T & D1020T & D1040T \\
\hline Moisture & $9.920 \pm 0.21^{\mathrm{a}}$ & $9.99 \pm 0.11^{\mathrm{a}}$ & $9.42 \pm 0.60^{\mathrm{a}}$ & $9.82 \pm 0.32^{\mathrm{a}}$ & $10.00 \pm 0.0^{\mathrm{a}}$ \\
Crude Protein & $23.76 \pm 1.04^{\mathrm{abc}}$ & $22.73 \pm 2.20^{\mathrm{c}}$ & $23.12 \pm 0.90^{\mathrm{bc}}$ & $25.54 \pm 0.48^{\mathrm{ab}}$ & $26.17 \pm 1.6^{\mathrm{a}}$ \\
Crude Lipid & $7.95 \pm 0.03^{\mathrm{b}}$ & $6.67 \pm 0.60^{\mathrm{c}}$ & $6.44 \pm 0.48^{\mathrm{c}}$ & $7.68 \pm 0.27^{\mathrm{b}}$ & $8.88 \pm 0.09^{\mathrm{a}}$ \\
Crude Fibre & $29.85 \pm 1.44^{\mathrm{a}}$ & $28.48 \pm 0.6^{\mathrm{a}}$ & $28.85 \pm 1.21^{\mathrm{a}}$ & $29.49 \pm 0.26^{\mathrm{a}}$ & $26.40 \pm 1.1^{\mathrm{a}}$ \\
Ash & $6.22 \pm 0.15^{\mathrm{a}}$ & $6.27 \pm 0.10^{\mathrm{a}}$ & $6.24 \pm 0.08^{\mathrm{a}}$ & $6.25 \pm 0.08^{\mathrm{a}}$ & $6.14 \pm 0.05^{\mathrm{a}}$ \\
NFE & $2.22 \pm 1.80^{\mathrm{ab}}$ & $2.59 \pm 3.15^{\mathrm{a}}$ & $2.59 \pm 2.18^{\mathrm{a}}$ & $2.12 \pm 0.49^{\mathrm{b}}$ & $2.24 \pm 0.65^{\mathrm{ab}}$ \\
Energy kcal $/ \mathrm{g}$ & $3.00 \pm 0.61^{\mathrm{b}}$ & $2.97 \pm 0.06^{\mathrm{b}}$ & $2.97 \pm 0.01^{\mathrm{b}}$ & $3.03 \pm 0.01^{\mathrm{b}}$ & $3.23 \pm 0.07^{\mathrm{a}}$ \\
\hline
\end{tabular}

Row means without superscripts are not significantly different $(p>0.05)$ from each other 
Table 05: Acid Insoluble Analysis of the feed and faecal samples of Oreochromis niloticus

\begin{tabular}{lccccc}
\hline & CTR & D520T & D540T & D1020T & D1040T \\
\hline AIA Feed & $0.05 \pm 0.002^{\mathrm{d}}$ & $0.09 \pm 0.02^{\mathrm{c}}$ & $0.12 \pm 0.02^{\mathrm{c}}$ & $0.15 \pm 0.02^{\mathrm{b}}$ & $0.19 \pm 0.01^{\mathrm{a}}$ \\
AIA Faeces & $0.40 \pm 0.02^{\mathrm{e}}$ & $0.48 \pm 0.03^{\mathrm{d}}$ & $0.55 \pm 0.02^{\mathrm{c}}$ & $0.59 \pm 0.02^{\mathrm{b}}$ & $0.66 \pm 0.03^{\mathrm{a}}$ \\
\hline
\end{tabular}

Row means with different superscripts are significantly different $(p<0.05)$ from each other; AIA Acid Insoluble Ash

The apparent digestibility coefficients (ADC) of nutrients in diets containing differently timed dry heat treated Jatropha curcas seedmeal fed to Nile tilapia is presented in Table 06. The ADC of nutrients in control diets were significantly $(\mathrm{p}<0.05)$ higher than that test diets containing Jatropha curcas seedmeal. There was no significant difference in the apparent organic matter digestibility, apparent protein digestibility, apparent lipid digestibility, apparent energy digestibility, apparent ash digestibility and apparent fibre digestibility between fish fed D520T and D540T. Superior performance obtained in the soybean-based control diets compared to Jatropha curcas based test diets in this study corroborates with the report of Fagbenro (1998) that apparent digestibility coefficient of soybean meal was higher when compared to other legumes. This explains why soybeanbased control diets had superior performance in its nutrient digestibility. Furthermore, Jatropha curcas is known to contain Phorbol Ester, a thermo-stable anti-nutritional factor, which has capacity to reduce the utilization of the seedmeal in fish. Relatively lower digestibility coefficients of nutrients in the test diets which reduces with increasing replacement level could be plausibly due to antinutrient in Jatropha seedmeal which limits their bioavailability (Glencross et al., 2007; Makkar et al., 2008). Kumar et al., (2009) reported that higher concentration of the antinutritional factors reduces the digestibility of protein in the diets and also the higher crude fibre could hinder the protein availability of the diets. Control feed had the lowest crude fibre content which is significantly lower than the crude fibre of other test diets. Keembiyeethy and Desilva, (1993) reported that high fibre contents in diets could result in increased weight of excreta and reduced nutrient absorption causing lowered nutrient digestibility. The fibre content of the test dietary treatments being higher than that of the control could be a pointer to the low digestibility of the nutrient in them. Mohanta et al., (2006) recorded similar observation when digestibility coefficients of some commonly used feed ingredients in pelleted diets for silver barb was assessed. Lower digestibility values of the nutrients in the plant materials were attributed to the fibrous material of the feed ingredients which were either poorly digestible or indigestible at all.

Table 06: Apparent digestibility coefficients of nutrients in diets containing Jatropha curcas seedmeal fed to Nile tilapia

\begin{tabular}{lccccc}
\hline & CTR & D520T & D540T & D1020T & D1040T \\
\hline AOMD & $88.47 \pm 1.16^{\mathrm{a}}$ & $80.83 \pm 2.61^{\mathrm{b}}$ & $78.53 \pm 2.31^{\mathrm{b}}$ & $74.53 \pm 2.47^{\mathrm{c}}$ & $70.50 \pm 0.75^{\mathrm{d}}$ \\
APD & $92.22 \pm 0.62^{\mathrm{a}}$ & $87.72 \pm 0.52^{\mathrm{b}}$ & $85.90 \pm 1.11^{\mathrm{b}}$ & $81.51 \pm 1.78^{\mathrm{c}}$ & $78.04 \pm 1.49^{\mathrm{d}}$ \\
ALD & $91.24 \pm 1.03^{\mathrm{a}}$ & $88.09 \pm 0.47^{\mathrm{b}}$ & $86.76 \pm 0.46^{\mathrm{b}}$ & $81.11 \pm 2.45^{\mathrm{c}}$ & $74.76 \pm 0.78^{\mathrm{d}}$ \\
AED & $91.43 \pm 1.02^{\mathrm{a}}$ & $85.86 \pm 1.68^{\mathrm{b}}$ & $84.09 \pm 1.72^{\mathrm{b}}$ & $80.57 \pm 1.88^{\mathrm{c}}$ & $76.10 \pm 0.58^{\mathrm{d}}$ \\
AAD & $88.85 \pm 1.19^{\mathrm{a}}$ & $81.53 \pm 2.36^{\mathrm{b}}$ & $79.44 \pm 2.10^{\mathrm{b}}$ & $75.03 \pm 2.61^{\mathrm{c}}$ & $70.73 \pm 0.58^{\mathrm{d}}$ \\
AFD & $71.20 \pm 1.44^{\mathrm{a}}$ & $56.08 \pm 4.57^{\mathrm{b}}$ & $50.99 \pm 3.91^{\mathrm{b}}$ & $42.94 \pm 5.61^{\mathrm{c}}$ & $41.27 \pm 3.73^{\mathrm{c}}$ \\
ACD & $90.07 \pm 1.81^{\mathrm{a}}$ & $80.08 \pm 5.47^{\mathrm{b}}$ & $78.15 \pm 4.20^{\mathrm{b}}$ & $78.21 \pm 1.59^{\mathrm{b}}$ & $73.66 \pm 1.16^{\mathrm{b}}$ \\
\hline
\end{tabular}


There was a reduction in the apparent digestibility coefficients of nutrients in the diet with increase replacement levels which was significant $(p<0.05)$ at higher processing time. However, no significant difference $(p>0.05)$ was observed in the ADC of nutrients in D520T and D540T among the fish fed diets. Kamarudin et al., (1989) reported ADC crude protein value as high as $91.6 \%$. The values recorded for ADC crude protein of our test dietary treatments is lesser than this however, the control diets had a higher value than the reported value of control diets. Fagbenro et al., (1998) reported an ADC crude protein values between 81.9 and $88.5 \%$ for various legume seedmeal fed to Nile tilapia. The ADC crude protein values reported in this study fell within the range value reported in Mohanta et al., (2006) for Puntius gonionotus suggesting that tilapia digest the plant materials relatively well. Our results agree with the report of Jafri \& Anwar 1995 for grass carp; Hossain et al., (1997) for rohu carp; Nandeesha et al., (1991) for Catla catla.

The apparent energy digestibility coefficient and apparent organic matter coefficient by fish fed control diet were significantly different $(p<0.05)$ from those fed test dietary treatments. The apparent energy digestibility reduces with processing time and inclusion level. The values recorded in this study were higher than the value reported for various legume seedmeal fed to Nile tilapia by Fagbenro (1998). The apparent energy digestibility values recorded in this study varied from 76.10 to $91.40 \%$. Values reported in earlier studies by Hossain and Jauncey (1989) for common were $69.9-72.1 \%$. Kamarudin et al., (1989) reported $77.4-88.3 \%$ in red tilapia; Our values are closely related to this value reported in Kamarudin et al., (1989). Higher lipid digestibility recorded in this study could contribute to this as lipid is the main source of digestible energy in fish. Previous reports on apparent lipid digestibility for various fish species were $79.6-90.2 \%$ for Nile Nile tilapia (De Silva et al., 1989); Nandeesha et al., (1991 reported a range of 69.6 to 86.4 for rohu. A higher value of apparent lipid digestibility coefficient of 90.4 to 94.1\% was reported by Hossain et al., (1997). Our recorded value of apparent lipid digestibility coefficient in this report fell within 74.76 and 91.24 which suggest that tilapia highly digested the oil in the various dietary treatments relatively well.

The apparent carbohydrate digestibility coefficient of fish fed control diets also followed the same trend as recorded above for apparent energy and organic matter digestibility. The carbohydrate digestibility reduces with processing time and inclusion level although they were not statistically different $(p>0.05)$ from each other. The results of apparent carbohydrate digestibility coefficients obtained in this study were higher than the value reported in Jimoh et al., (2010) and Jimoh et al., (2014). The digestibility of carbohydrate is known to vary with inclusion level, complexity and source treatment (Lovell, 1977; Cho and Slinger, 1979) and tilapia can digest carbohydrate relatively well than other fish species (Lovell, 1977). Results on digestibility coefficient of nutrients in plant materials vary due to environmental conditions of the culture system, manufacturing technique and feeding practices (Mcgoogan and Reigh, 1996; Mohatan et al., 2006).

\section{CONCLUSION}

It is evident from the earlier studies as well as this study that soybean meal-based diets have high digestibility coefficients perhaps because of its better nutrient profile. It is evident from this study that diets containing Jatropha curcas seedmeal were relatively comparably well digested by Oreochromis niloticus and should be further investigated to seek the opportunity as an alternative feed ingredients to soybean meal.

\section{REFERENCES}

Adeparusi E.O. \& Jimoh W.A. (2002). Digestibility coefficients of raw and processed lima bean diet for Nile Tilapia, Oreochromis niloticus. Journal of Applied Aquaculture. 12 (3), pp. 89-98. https://doi.org/10.1300/J028v12n03_09 
Association of Official Analytical Chemists (AOAC) (1990). Official method of analysis. K. Helrich (ed).15th edn, vol 1, AOAC, Arlington, VA,pp 684.

Borghesi R., Portz L., Oetterer M. and Cyrino J.E.P. (2008). Apparent digestibility coefficient of protein and amino acids of acid, biological and enzymatic silage for Nile Tilapia (Oreochromis niloticus). Aquaculture Nutrition, 14: 242 - 248.

https://doi.org/10.1111/j.1365-2095.2007.00523.x

Cho E.Y. \& Slinger S. L. (1979). Apparent digestibility measurement in foodstuff for rainbow trout, in J.O. Halver and K. Tiews Eds. World Symposium on Fin Fish Nutrition and Fish Feed Technology Heinemann, Berlin. Germany. 2:239 - 247.

De Silva, S.S., Keembiyahetty, C.N. and Gunasekera, R.M. (1988). Plant ingredient substitutes in Oreochromis niloticus (L.) diets: ingredient digestibility and effect of dietary protein content on digestibility. Journal of Aquaculture in the Tropics., 3:127-138.

Fagbenro A.O. (1998), Apparent digestibility of various legume seedmeals in Nile tilapia diets short communication. Aquaculture International. 6: 83-87.

Fagbenro O. A., Adeparusi E. O. and Jimoh W. A. (2013). Apparent nutrient digestibility of sunflower and sesame seed meal in Clarias gariepinus (Burchell, 1822) fingerlings. Journal of Fisheries and Aquatic Sciences 8(1):43-50. https://doi.org/10.3923/jfas.2013.43.50

Glencross D. B., Booth M. and Allan L.G. (2007). A feed is only as good as its ingredients. A review of ingredients evaluation strategies for aquaculture feeds. Aquaculture Nutrition 13:17-34. https://doi.org/10.1111/j.1365-2095.2007.00450.x

Goddard J.S. \& McLean L.C. (2001). Acid-insoluble ash as an inert reference material for digestibility studies in tilapia, Oreochromis niloticus. Aquaculture 194: 93-98.

https://doi.org/10.1016/S0044-8486(00)00499-3

Gul Y., Salim M. and Rabbani B. (2007). Evaluation of apparent digestibility coefficients of different dietary protein levels with and without fishmeal for Labeo rohita. Pakistan Veterinary Journal 27 (3): 121-125.

Halver J.C., Yiman A., and Smith R.R. (1993). Acid Insoluble Ash as a convenient method for estimating digestible components in diet. in proceeding international conference world on Aquaculture and fresh water fish. pp 230

Hardy, R.W. (2010). Utilization of plant proteins in fish diets: effects of global demand and supplies of fishmeal. Aquaculture Research.41(5):770-776. https://doi.org/10.1111/j.13652109.2009.02349.x

Hossain, M.A., Nahar, N., Kamal, M. and Islam, M.N. (1992). Nutrient digestibility coefficient of some plants and animal proteins for tilapia (Oreochromis niloticus). Journal of Aquaculture in the Tropics. 7: 257-260

Hossain, M.A. \& Jauncey K. (1989). Studies on the protein, energy and amino acid digestibility of fish meal, mustard oil cake, linseed and sesame for common carp (Cyprinus carpio L.). Aquaculture. 83: 59-72. https://doi.org/10.1016/0044-8486(89)90060-4 
Hossain, M.A., Nahar, N. and Kamal, M. (1997) Nutrient digestibility coefficient of some plant and animal proteins for rohu (Labeo rohita). Aquaculture. 151: 37-45. https://doi.org/10.1016/ S0044-8486(96)01481-0

Jafri, A.K. \& Anwar, M.F. (1995) Protein digestibility of some-low cost feed stuffs in fingerlings Indian major carps. Asian Fisheries Science. 8: 47-53.

Jimoh, W. A., Fagbenro, O. A. and Adeparusi, E. O. (2010). Digestibility coefficients of processed jackbean meal for Nile Tilapia, Oreochromis niloticus diets. International Journal of Fisheries and Aquaculture. 2(4): 102-107.

Jimoh, W.A., Awodele, A.O., Okemakin, F.Y., Ayeloja, A.A. Abdusalami, S.A. and Azeez, F.A. (2015). Apparent digestibility experiment with tilapia fed diets containing Citrullus lanatus seedmeal. Annals of West University of Timişoara, serial Biology, 2015, 18 (2):159-168.

Kamarudin, M.S., Kalipan, K.M. and Siraj, S.S. (1989) The digestibility of several feed stuffs in red tilapia. In: Fish Nutrition Research in Asia. Proceedings of the Third Asian Fish Nutrition Network Meeting (De Silva, S.S. ed.), Asian Fisheries Society Special. Publication No. 4. Asian Fisheries Society, Manila, Philippines. pp. 118-122

Keembiyehetty, C. N. and De Silva, S. S. (1993). Performance of juvenile Oreochromis niloticus (L.) reared on diets containing cowpea Vigna catiang and black gram Phaseolus mungo seeds. Aquaculture. 112: 207-215. https://doi.org/10.1016/0044-8486(93)90446-6

Köprücü, K. and Özdemir, Y. (2005). Apparent digestibility of selected feed ingredients for Nile Tilapia (Oreochromis niloticus). Aquaculture.250:308 - 316. https://doi.org/10.1016/j. aquaculture.2004.12.003

Kumar, V., Makkar, H.P.S. and Becker, K. (2009).Detoxification of Jatropha curcas seed meal and its utiliization as a protein source in fish diet. Comparative Biochemistry and Physioliology. 151A(1): 13-14. https://doi.org/10.1016/j.cbpa.2008.05.025

Lovell, R.T. (1977). Digestibility of nutrients in feedstuff of Catfish. In nutrition and feeding of channel catfish by R.R. Stickney, R.T. Lovell (eds) southern cooperative series. Bulletin 218. Auburn, Ala, Auburn University.

Luquet, P. (1991). Tilapia (Oreochromis Spp) in R.P Wilson (ed). CRC handbook of fin fish. CRC press, Inc. Florida. pp 161-179

Makkar H.P.S., Francis G. and Becker K. (2008). Protein concentrate from Jatropha curcas screwpressed seed cake and toxic and antinutritional factors in protein concentrate. Journal of the Science of Food and Agriculture. 88(9):1542-1548. https://doi.org/10.1002/jsfa.3248

McGoogan, B.B. \& Reigh, R.C. (1996) Apparent digestibility of selected ingredients in red drum (Sciaenops ocellatus) diets. Aquaculture. 141: 233-244. https://doi.org/10.1016/00448486(95)01217-6

Mohanta, K.N., Mohanty, S.N., Jena, J.K. and Sahu N.P. (2006). Apparent protein, lipid and energy digestibility coefficients of some commonly used feed ingredients in formulated pelleted diets for silver barb, Puntius gonionotus. Aquaculture Nutrition. 12: 211-218. https://doi.org/10.1111/ j.1365-2095.2006.00403.x 
Nandeesha, M.C., Srikanth, G.K., Keshavnath, P. and Das, S.K. (1991). Protein and fat digestibility of five feed ingredients by Indian major carp, Catla catla (Hamilton). In: Fish Nutrition Research in Asia. Proceeding of Fourth Asian Fish Nutrition Workshop (De Silva, S.S. ed.), Asian Fisheries Society, Manila, Philippine. pp. 75-81.

Sarker, P.K., Gamble, M.M., Kelson, S., and Kapuscinski, A.R. (2016). Nile tilapia (Oreochromis niloticus) show high digestibility of lipid and fatty acids from marine Schizochytrium sp. and of protein and essential amino acids from freshwater Spirulina sp. feed ingredients. Aquaculture Nutrition. 22(1): 109-119. https://doi.org/10.1111/anu.12230

Satoh S, Cho C.Y. and Watanabe T (1992). Effect of fecal retrieval timing on digestibility of nutrients in rainbow trout diet with the Guelph and TUF faeces collection systems. Nippon Suisan Gakkaishi. 58: 1123-1127. https://doi.org/10.2331/suisan.58.1123

Siddhuraju P. \& Becker K. (2001). Preliminary nutritional evaluation of mucuna seed meal (Mucuna pruriens var. utilis) in common carp (Cyprinus carpio L.): An assessment by growth performance and feed utilization. Aquaculture. 196: 105 - 123. https://doi.org/10.1016/S00448486(00)00577-9

Smith R. R. (1989). Nutritional energetic. in fish nutrition (J.E Halver eds).New York Academic Press. pp. 1-29

Takeuchi T., Watanabe, T. and Ogino C. (1979). Digestibility of hydrogenated fish oils in carp and rainbow trout. Bulletin of the Japanese Society of Scientific Fisheries. 45: 1521-1525. https:// doi.org/10.2331/suisan.46.1521

Wilson R.P. \& Poe W. E. (1985). Apparent digestibility of protein and energy in feed ingredients for channel catfish. Progressive Fish-Culturist, 47: 154-158. https://doi.org/10.1577/15488640(1985)47<154:ADPAEC $>2.0 . \mathrm{CO} ; 2$ 